\author{
Maria Kózka \\ Tomasz Brzostek ${ }^{1}$ \\ Maria Cisek ${ }^{1}$ \\ Piotr Brzyski $i^{2}$ \\ Lucyna Przewoźniak \\ Teresa Gabrys' ${ }^{1}$ \\ Maria Ogarek ${ }^{1}$ \\ Krzysztof Gajda ${ }^{3}$ \\ Anna Ksykiewicz-Dorota ${ }^{4}$
}

ORIGINAL PAPER

\title{
FACTORS AFFECTING POLISH NURSES' WILLINGNESS TO RECOMMEND THE HOSPITAL AS A PLACE OF CARE
}

\author{
CZYNNIKI WPŁYWAJĄCE NA GOTOWOŚĆ POLSKICH PIELĘGNIAREK \\ DO REKOMENDOWANIA SZPITALA JAKO MIEJSCA OPIEKI
}

\author{
${ }^{1}$ Jagiellonian University Medical College / Collegium Medicum Uniwersytetu Jagiellońskiego, Kraków, Poland \\ Faculty of Health Sciences, Institute of Nursing and Midwifery / Wydział Nauk o Zdrowiu, Instytut Pielęgniarstwa i Położnictwa \\ ${ }^{2}$ Jagiellonian University Medical College / Collegium Medicum Uniwersytetu Jagiellońskiego, Kraków, Poland \\ Department of Medical Sociology, Chair of Epidemiology and Preventive Medicine / Zakład Socjologii Medycyny, Katedra Epidemiologii \\ i Medycyny Zapobiegawczej \\ ${ }^{3}$ Jagiellonian University Medical College / Collegium Medicum Uniwersytetu Jagiellońskiego, Kraków, Poland \\ Faculty of Health Sciences, Institute of Public Health / Wydział Nauk o Zdrowiu, Instytut Zdrowia Publicznego \\ ${ }^{4}$ Medical University of Lublin / Uniwersytet Medyczny w Lublinie, Lublin, Poland \\ Faculty of Health Science, Chair and Department of Management in Nursing / Wydział Nauk o Zdrowiu, Katedra i Zakład Zarządzania \\ w Pielęgniarstwie
}

\begin{abstract}
Background: Nurses constitute the major professional group offering constant hospital patients' care. Willingness to recommend their hospital reflects confidence in the offered care, satisfaction and identification with the work place. The aim of the present study has been to investigate which elements of hospital environment and nurse personal related factors predict recommendation of the hospital as a place of care by employed nurses. Material and Methods: Cross-sectional, correlation study was, based on 1723 self-reported, anonymous questionnaires of nurses working in 30 acute hospitals. Data was analyzed using the logistic regression model, with general estimation equations. Results: About $25 \%$ of nurses were unwilling to recommend their hospital as the place of care. The odds ratio (OR) of the lack of willingness to recommend the hospital was related to assessment of patients' safety $(\mathrm{OR}=0.28,95 \%$ confidence interval $(\mathrm{CI}): 0.18-0.46, \mathrm{p}=0.00)$, decrease in the quality of patient care during the preceding year $(\mathrm{OR}=0.62,95 \% \mathrm{CI}: 0.41-0.93, \mathrm{p}=0.02)$, overall work conditions $(\mathrm{OR}=0.35,95 \% \mathrm{CI}$ : $0.22-0.57, \mathrm{p}=0.00)$, weak cooperation between nurses and physicians $(\mathrm{OR}=0.37,95 \% \mathrm{CI}: 0.25-0.54, \mathrm{p}=0.00)$, poor work schedule flexibility $(\mathrm{OR}=0.74,95 \% \mathrm{CI}$ : $0.55-$ $0.99, \mathrm{p}=0.04)$ and educational opportunities (OR $=0.71,95 \% \mathrm{CI}: 0.54-0.95, \mathrm{p}=0.02)$ and the level of nurses depersonalization $(\mathrm{OR}=1.78,95 \% \mathrm{CI}: 1.18-1.68, \mathrm{p}=0.00)$. Conclusions: The hospital manager should consider strategies which improve patients' safety and the staff working conditions. Thanks to that they will also achieve better and more competitive image of the hospital in the local community. Med Pr 2016;67(4):447-454
\end{abstract}

Key words: safety, nurses, work, environment, hospital, depersonalisation

\section{STRESZCZENIE}

Wstęp: Pielęgniarki są znaczącą grupą zawodową personelu szpitalnego, która obejmuje pacjentów stałą opieką. Gotowość pielęgniarek do polecenia szpitala, w którym pracują, jako miejsca opieki odzwierciedla ich zaufanie do oferowanej w nim opieki, satysfakcję z pracy i identyfikację z miejscem pracy. Celem badania było określenie, które czynniki środowiska pracy i związane z nimi czynniki zawodowe i/lub osobiste sprawiają, że pielęgniarki rekomendują szpital jako miejsce opieki. Materiał i metody: Przekrojowe badania korelacyjne bazowały na anonimowych ankietach uzyskanych od 1723 pielęgniarek pracujących w 30 polskich szpitalach. Dane analizowano przy użyciu modelu regresji logistycznej szacowanego za pomocą uogólnionych równań estymujących. Wyniki: Około $25 \%$ pielęgniarek nie poleciłoby swojego szpitala jako miejsca opieki. Wynikało to $\mathrm{z}$ negatywnej oceny bezpieczeństwa pacjenta (iloraz szans (odds ratio - OR) = 0,28; 95-procentowy przedział ufności (confidence

Funding / Finansowanie: the European Community's Seventh Framework Programme (FP7/2009-2011), project No. 223468 entitled “Registered Nurse Forecasting (RN4 CAST) study." Project manager: Prof. Tomasz Brzostek, Ph.D. 
interval - CI): 0,18-0,46; $\mathrm{p}=0,00)$, pogorszenia jakości opieki w roku poprzedzającym badanie $(\mathrm{OR}=0,62 ; 95 \%$ CI: 0,41-0,93; $\mathrm{p}=0,02)$, niezadowalających warunków pracy $(\mathrm{OR}=0,35 ; 95 \% \mathrm{CI}: 0,22-0,57 ; \mathrm{p}=0,00)$, niezadowalającej współpracy lekarzy z pielęgniarkami $(\mathrm{OR}=0,37 ; 95 \% \mathrm{CI}: 0,25-0,54 ; \mathrm{p}=0,00)$, mało elastycznego czasu pracy $(\mathrm{OR}=0,74 ; 95 \% \mathrm{CI}: 0,55-0,99 ; \mathrm{p}=0,04)$, ograniczonych możliwości dokształcania się (OR =0,71; 95\% CI: 0,54-0,95; $\mathrm{p}=0,02)$ i wysokiego poziomu depersonalizacji badanych $(\mathrm{OR}=1,78 ; 95 \% \mathrm{CI}: 1,18-1,68 ; \mathrm{p}=0,00)$. Wnioski: Zarządzający szpitalami powinni wdrożyć strategie, które poprawią bezpieczeństwo pacjentów i warunki pracy personelu. Pozwoli to również stworzyć lepszy i bardziej konkurencyjny wizerunek szpitala w społeczności lokalnej. Med. Pr. 2016;67(4):447-454

Słowa kluczowe: bezpieczeństwo, pielęgniarki, praca, środowisko, szpital, depersonalizacja

Corresponding author / Autorka do korespondencji: Maria Kózka, Jagiellonian University Medical College,

Faculty of Health Sciences, Institute of Nursing and Midwifery, Kopernika 25, 31-501 Kraków, Poland,

e-mail: maria.kozka@uj.edu.pl

Received: October 27, 2015, accepted: March 9, 2016

\section{INTRODUCTION}

In public hospitals, which in Poland account for $70 \%$ of all hospitals [1], acute healthcare services are provided, without the need for any referral. In elective states, every insured patient has the right to choose the hospital, on condition that he or she has been referred by a physician. In practice, there is a risk that the hospital choice is restricted by the financial resources earmarked by the paying authority (National Healthcare Fund) [2]. The value of the contract received by the hospital depends on a number of factors, including the number of medical personnel, their professional qualifications, the facilities offered by the hospital, its reference level, and the quality of the offered services [3].

Creation of the hospitals imaging began in Poland in the late 1990s. The process has been closely connected with the development of competition in healthcare services available in the market and the launch of non-public hospitals [4]. For the benefit of its social mission and due to competition of healthcare services, hospitals should strive for a good opinion and patients' trust. The research conducted in 2010 by the Public Opinion Research Center (Centrum Badania Opinii Społecznej-CBOS) proved that $36 \%$ of respondents participating in the study were strongly dissatisfied with the healthcare system, 39\% remained rather dissatisfied, while $20 \%$ of the respondents were rather satisfied, only $2 \%$ of responders was definitely satisfied with the functioning of the healthcare system [5]. Assurance of high-quality healthcare services strongly influenced the positive opinion about the hospital [6].

Factors decisive for the level of health care include: the type and quality of the healthcare services provided, quality of medical and nursing care, cooperation between the members of the healthcare team, organizational and technical conditions, and the hospital management [6]. Nursing care is an integral part of healthcare and carries the same features as the entire system. The following factors are considered essential for quality of nursing care: safety, efficiency, availability, continuity, flexibility, individualization of care to the patient's needs, promotion of health and prevention of illnesses, professionalism of care services in line with current knowledge and standards of practice including appropriate resources and technical support $[7,8]$.

Nurses are the largest group of medical personnel employed in hospitals [9]. Delivering continuous hospital care of the patient, nurses possess knowledge that lets them assess environment of hospital health care services in various aspects. Their work engagement and effectiveness contribute to patients' safety and satisfaction [10]. Efficiency of nurse work, constant relation with the patients and within the professional group, translate into the hospital image perceived by hospitalized patients and further transferred to community [11]. Significant participation of nurses in the hospital care has been confirmed in the hospital accreditation process [7].

The hospital recommendation as the place of care to close friends or relatives might reflect personal attitudes towards hospital and its role in the community. In Poland nurses have enjoyed high social trust [12], and therefore may have a potential influence on the opinion about the hospital in the society. This study intends to provide hospital chief executive officers with evidencebased approach to find factors that might essentially influence the opinions of nurses about the hospital as the place of care, work environment and nurse personal spectrum. So far, according to the authors' knowledge, no studies relating to nurses' hospital care recommendation to different aspects of work environment, based on the country representative hospital sample have been published in Poland. 


\section{MATERIAL AND METHODS}

Study design: cross-selectional, correlational. The study presents the results obtained on a country representative sample of 30 acute hospitals (57 surgical and 62 medical wards) of different reference levels, selected according to the Registered Nurse Forecasting (RN4CAST) study protocol [13]. The study was approved by the Jagiellonian University Bioethical Committee, the data was collected in 2010.

The respondents - 1723 nurses were mostly women $(0.6 \%$ men). All respondents were registered nurses (RN), and $23 \%$ had acquired a bachelor degree. The majority $(98 \%)$ were in full-time employment. The medium respondents age was 40 years old (standard deviation $(\mathrm{SD})=8$ ); average age when obtained $\mathrm{RN}$ was $20.7 \pm 1.5$ years old; professional employment time as the RN was $18.4 \pm 8.6$ years; and in this hospital $15.3 \pm 9.2$ years. The largest group of nurses was employed in the regional (52\%) and specialist (32.7\%) hospitals.

The willingness to recommend the hospital was measured with the question: "Would you recommend your hospital to your friends and family if they need hospital care?" This question had 4 possible answers: "Definitely not," "Probably not," "Probably yes," and "Definitely yes." The first 2 answers were grouped into one category indicating the lack of willingness to recommend the hospital. The 2 remaining answers were grouped into another category indicating willingness to recommend the hospital.

The hospital type and nurse demographic data was used as potential independent predictors of willingness to recommend a hospital. The time of employment in the hospital was used as a continuous variable. The type of ward was used as a binary variable distinguishing nurses working on a medical ward from those working on a surgical ward.

Nurse's satisfaction with different aspects of the work environment was measured as dichotomous variables indicating those who were satisfied with a particular aspect of the work, as opposed to those who were not satisfied. Only relationships between work schedule flexibility, educational opportunities, and the opportunity to obtain study leave significantly influenced the nurses' willingness to recommend the hospital and were included in the final model.

All subscales of the Practical Environment Scale of Nursing Work Environment Index (PES/NWI) including: nurse-physician relations, nurse participation in hospital affairs, nurse managerial ability, leadership and nurse support, nursing foundation for quality of care [14]; and of Maslach Burnout Inventory (MBI) subscales including: emotional exhaustion, depersonalization and personal accomplishments [15]; were divided into three categories, using quartiles distribution values: values lower than or equal to the 1st quartile were classified as a low, whereas values equal or higher than the 3rd quartile were classified as a high level of particular variables. Values between the 1st and 3rd quartiles were classified as medium. Only the relationship between levels of depersonalization (subscale of MBI) and cooperation between nurses and physicians (subscale of PES/NWI) significantly influenced nurse willingness to recommend the hospital, and these variables were included in the final model.

The general assessment of the working conditions was measured with the question: "How would you rate the work environment at your job in this hospital (considering adequacy of resources, relations with co-workers, support from supervisors)?" This variable had 4 answer categories: "poor," "fair," "good" and "excellent." For the purpose of this analysis, the two last categories were joined together.

The general assessment of patients' safety on the ward was measured with the instruction: "Please give your unit/ward an overall grade on patients' safety." This variable had a 5-item response scale: from "failing," via "poor," "acceptable," and "good" to "excellent." The last two categories (good and excellent) were joined into one category called "high" whereas the two lowest (failing and poor) were joined into one category called "low."

The change in the quality of medical care at the hospital was measured with the question: "In the previous year would the quality of patients' care in your hospital has ...," which could be completed with one of the three options provided: "deteriorated," "remained the same," or "improved."

The possibility of the staff questioning the decisions of the manager was measured with the statement: "The staff feels free to question the decisions or actions of those in authority." This variable had a 5-item Likert response scale, ranging from "strongly disagree" to "strongly agree." The categories "strongly agree" and "agree" were joined into one category called "yes," while the three other categories were joined into a single category called "no."

The statistics was generated using the IBM SPSS Statistics 19 for Windows statistical software. 
Categorical data was described as observed absolute (n) and relative (\%) frequencies. Continuous variables were described with mean (M) and SD. Independent predictors of willingness to recommend the hospital as a place of care were assessed with the logistic regression model, estimated with generalized estimating equations. Hospital identifiers (ID, the number of the hospital and the number of hospital branch, respectively) were used as subject variables. $P$ values of less than 0.05 were considered statistically significant.

\section{RESULTS}

In the representative sample of Polish hospitals participating in the Registered Nurse Forecasting (RN4CAST) study $24.5 \%$ RN (interquartile range (IQR) $=18-39.25 \%$ ) were not willing to recommend the hospital as a place for care.

Safety on the ward was acknowledged to be high by more than one nurse out of four, while approximately every fifth considered it to be low. Nearly one-fifth of the respondents believed that the quality of care in their hospital had deteriorated during the previous year; improvement was declared by nearly every fourth of respondents. Less than a quarter of the nurses recognized the conditions of working in the hospital as high, while nearly one-third considered them to be low.

Approximately three quarters of the nurses were satisfied with the flexibility of the working hours, more than a half with the possibility of education, and one out of three with the opportunity to obtain study leave. A majority of the nurses in the study group claimed that it was impossible to question the decisions or actions of superiors (Table 1).

The multivariate model of logistic regression showed that the odds of recommending the hospital as a place of care increased along with the increasing assessment of patients' safety on the ward, and with the improvement of the quality of care during the preceding year. Increasing general assessment of working conditions was a favorable factor for recommending the hospital. Satisfaction with work flexibility and educational opportunities was correlated with higher odds of recommending the hospital. Higher assessment of nurse-physician cooperation was related to higher odds of recommending the hospital by respondents. Longer duration of employment in the current hospital was concomitant with the increase in odds of recommending the hospital. Greater depersonalization, as the only dimension of the Maslach Burnout Inventory, was associated with increased odds of not recommending the hospital. The reference level of the hospital and type of ward did not significantly influence the probability of recommending the hospital (Table 2).

\section{DISCUSSION}

This is the first publication of this type to present comprehensive country data, based on a representative sample acquired from 1723 nurses employed in 30 public hospitals, selected according to territorial criteria, population density, and level of reference in Poland, according to the international RN4CAST protocol [13].

Nearly three quarters of Polish nurses were ready to recommend the hospital. The percentage share of nurses' willingness to recommend the hospital as a place of care in the RN4CAST study countries differed across Europe [8].

The novelty of the study indicates that hospital chief executive officers (managers) organizational efforts to improve patients' safety and personnel work environment has a positive influence on the willingness to recommend the hospital as a place of care by employed nurses. The most important findings demonstrated that the nurses pointed to the decisive quality of those conditions of work that were directly related to patient safety and quality of care including team work. They also encompassed flexibility of working time and potential for professional development. Readiness to recommend was also influenced by the duration of employment in the hospital. The level of depersonalization was an independent factor negatively correlated to the readiness to recommend the hospital care by team played nurses.

The identified predictors are in line with Zhan and Yang [16] who stated that patients' safety was the main constituent of healthcare quality. Hughes and Clancy [17] believe that the managers of a healthcare facility are responsible for the quality of care. The success of the chief managers is measured by the organization's ability to deliver effective treatment and safety care to the patients, with satisfaction for the patients and caregiver alike [18] assign a fundamental role to nursing leadership in determining the quality of work-life. Nursing leadership and a practice work environment are related to patients' safety but also to a lower burnout among nurses [8].

Our results indicate that team work, as reflected by the cooperation between nurses and physicians, is a significant factor influencing readiness to recommend the hospital as a place of care. Cooperation in a team provides 
Table 1. Nurses' willingness to recommend hospital in which they work as a place of care

Tabela 1. Gotowość pielęgniarek do rekomendowania szpitala, w którym pracują, jako miejsca opieki

\begin{tabular}{|c|c|c|}
\hline \multirow[t]{2}{*}{$\begin{array}{l}\text { Independent variable } \\
\text { Zmienna niezależna }\end{array}$} & \multicolumn{2}{|c|}{$\begin{array}{c}\text { Respondents } \\
\text { Badani } \\
(\mathrm{N}=1723)\end{array}$} \\
\hline & $\mathrm{n}$ & $\%$ \\
\hline \multicolumn{3}{|l|}{ Hospital / Szpital } \\
\hline clinical / kliniczny & 264 & 15.3 \\
\hline \multicolumn{3}{|l|}{ Ward / Oddział } \\
\hline surgical / chirurgiczny & 848 & 49.2 \\
\hline internal / internistyczny & 875 & 50.8 \\
\hline \multicolumn{3}{|c|}{ Comprehensive assessment of safety on the ward / Całościowa ocena bezpieczeństwa na oddziale } \\
\hline \multicolumn{3}{|l|}{ Change of care quality in the last year / Zmiana jakości opieki w ostatnim roku } \\
\hline no changes / bez zmian & 1008 & 58.5 \\
\hline deterioration / pogorszenie & 307 & 17.8 \\
\hline improvement / poprawa & 408 & 23.7 \\
\hline \multicolumn{3}{|l|}{ General assessment of working conditions / Ogólna ocena warunków pracy } \\
\hline low / niska & 505 & 29.3 \\
\hline medium / średnia & 819 & 47.5 \\
\hline high / wysoka & 399 & 23.2 \\
\hline \multicolumn{3}{|c|}{ Satisfaction with work schedule flexibility / Zadowolenie z elastycznego czasu pracy } \\
\hline \multicolumn{3}{|c|}{ Satisfaction with the opportunity to obtain study leaves / Zadowolenie z możliwości uzyskania urlopu na studiowanie } \\
\hline yes / tak & 670 & 38.9 \\
\hline no / nie & 1053 & 61.1 \\
\hline \multicolumn{3}{|c|}{ Nurse-physician cooperation assessment / Ocena współpracy pielęgniarki z lekarzem } \\
\hline low / niska & 423 & 24.6 \\
\hline medium / średnia & 890 & 51.7 \\
\hline high / wysoka & 410 & 23.8 \\
\hline \multicolumn{3}{|l|}{ Depersonalisation level / Poziom depersonalizacji } \\
\hline low / niski & 388 & 22.5 \\
\hline medium / średni & 937 & 54.4 \\
\hline high / wysoki & 398 & 23.1 \\
\hline \multicolumn{3}{|c|}{$\begin{array}{l}\text { Staff feels free to question the decisions or actions of those in authority / Personel ma możliwość kwestionowania } \\
\text { decyzji przełożonych }\end{array}$} \\
\hline yes / tak & 186 & 10.8 \\
\hline no / nie & 1537 & 89.2 \\
\hline
\end{tabular}

MBI - Maslach Burnout Inventory / Kwestionariusz Wypalenia Zawodowego Maslach. 
Table 2. Variables significantly influencing nurses' willingness to recommend their hospital as a place of care - logistic regression model* Tabela 2. Zmienne istotnie wpływające na gotowość rekomendowania przez pielęgniarki szpitala, w którym pracują, jako miejsca opieki - model regresji logistycznej*

\begin{tabular}{|c|c|c|c|}
\hline $\begin{array}{l}\text { Variable } \\
\text { Zmienna }\end{array}$ & $\mathrm{p}$ & OR & $95 \% \mathrm{CI}$ \\
\hline \multicolumn{4}{|l|}{ Comprehensive assessment of safety on the ward / Całościowa ocena bezpieczeństwa na oddziale } \\
\hline low / niska & & 1.00 & \\
\hline acceptable / akceptowalna & 0.01 & 0.67 & $0.48-0.92$ \\
\hline high / wysoka & 0.00 & 0.28 & $0.18-0.46$ \\
\hline \multicolumn{4}{|l|}{ Change of care quality in the last year / Zmiana jakości opieki w ostatnim roku } \\
\hline no change / bez zmian & & 1.00 & \\
\hline decrease / pogorszenie & 0.00 & 1.82 & $1.27-2.59$ \\
\hline increase / poprawa & 0.02 & 0.62 & $0.41-0.93$ \\
\hline \multicolumn{4}{|l|}{ General assessment of working conditions / Ogólna ocena warunków pracy } \\
\hline low / niska & & 1.00 & \\
\hline medium / średnia & 0.00 & 0.50 & $0.38-0.65$ \\
\hline high / wysoka & 0.00 & 0.35 & $0.22-0.57$ \\
\hline Satisfaction with work schedule flexibility: yes vs. no / Zadowolenie z elastycznego czasu pracy: tak vs nie & 0.04 & 0.74 & $0.55-0.99$ \\
\hline Satisfaction with education opportunities: yes vs. no / Zadowolenie z możliwości kształcenia: tak vs nie & 0.02 & 0.71 & $0.54-0.95$ \\
\hline \multicolumn{4}{|l|}{ Nurse-physician cooperation assessment / Ocena współpracy pielęgniarki z lekarzem } \\
\hline low / niska & & 1.00 & \\
\hline medium / średnia & 0.00 & 0.54 & $0.41-0.70$ \\
\hline high / wysoka & 0.00 & 0.37 & $0.25-0.54$ \\
\hline \multicolumn{4}{|l|}{ Depersonalisation level / Poziom depersonalizacji } \\
\hline low / niski & & 1.00 & \\
\hline medium / średni & 0.01 & 1.47 & $1.11-1.94$ \\
\hline high / wysoki & 0.01 & 1.78 & $1.18-2.68$ \\
\hline Duration of work at the hospital / Staż pracy w szpitalu & 0.00 & 0.98 & $0.96-0.99$ \\
\hline
\end{tabular}

* This model is adjusted for hospital type, type of the ward, possibility of obtaining study leave, and staff understanding that they can question the decisions or actions of those in authority / Model uwzględnia rodzaj szpitala i oddziału, możliwość uzyskania przez pielęgniarki urlopu na studiowanie i ich poczucie, że mogą kwestionować decyzje lub działania przełożonych.

OR - odds ratio / iloraz szans, CI - confidence interval / przedział ufności.

an important element of assessing quality and safety of care, and has been included in the standards for hospital accreditation process [19]. Hughes and Clancy [17] believe that safety in the hospital depends on the entire team, its knowledge, attitudes, views, competences, and behavioral patterns. The authors point out that it is a duty of the management of the ward to establish the so-called culture of safety, atmosphere of trust and support [17]. Good cooperation in a team could reduce wasted time, errors and resource consumption for all caregivers and help to achieve higher efficiency in actions, patient status and information $[4,20,21]$.

The duration of nurses' employment in the given hospital significantly influenced their willingness to recommend it, which might be related to getting accustomed to the work place or longer experience. Humel and Caputil [20] indicate professional experience is parallel to the extending work experience.

In our studies, the increasing level of depersonalization was an independent risk factor for not recom- 
mending the hospital as a place of care. The literature available emphasized the connection between burnout and conditions of work, including especially patient-tonurse ratios, working in shifts, duration of a shift, relationships inside the team, job satisfaction and pressure to extend the time spent at work [22-27]. Leiter and Spence Laschinger [18] emphasized the significance of nursing leaders, especially in the improvement of the personal accomplishment of the nurses and prevention of emotional exhaustion.

An especially negative influence on the level of emotional exhaustion and depersonalization of nurses is visible in the case of working under pressure or expectation for working beyond the normative working time [23]. The European Nurses' Exit Study (The European NEXT Study) [28] showed that only 55\% of Polish nurses were satisfied with their work, while in Polish studies this ratio was even lower (45\%).

Several authors $[4,29,30]$ believe that a positive opinion about a hospital expressed by its staff is connected to work efficiency and the level of care provided.

The limitation of this study may result from the fact that the change in the quality of care was evaluated not in a longitudinal study but only through a subjective comparison between the present state with the memorized situation a year earlier. Such an assessment may be loaded with both the fallibility of human memory and the possibility of the response shift which has been present in quality-of-life research, a phenomenon causing a change in the standards of assessment, leading to gentler interpretations of the phenomenon examined.

\section{CONCLUSIONS}

The results of our study indicate the importance of managerial efforts to improve working environment with special consideration of the quality of care and patients' safety, which are likely to repay with the promotion of the hospital. The determinants, significant for recommending the hospital as a place of care by the nurses, are also the factors that positively influence the life and healing of the hospitalized patients. The creation of a safe environment of care is the basic task of the hospital chief executive officers especially when policy of health care costs containment might exert negative consequences on the quality of care and potentially compensation cases. Hence, our results provide evidences that support hospital managers in conducting a long-term management policy with a positive effect on the hospital status and patient inflow.

\section{REFERENCES}

1. Central Statistical Office. [Health and health care 2012] [Internet]. Warszawa: The Office; 2013 [cited 2015 Jul 20]. Available from: http://stat.gov.pl/obszary-tematyczne/ zdrowie/zdrowie/zdrowie-i-ochrona-zdrowia-w-2012-r-, 1,3.html. Polish.

2. [The Act of 27 August 2004 on healthcare services financed from public funds. J Laws 2004, No. 210, item 2135]. Polish.

3. [Order of the President of the National Health Fund of 18 December 2013 on determining the conditions for the conclusion and execution of contracts concerning health care services contracted separately. Order 2013, No. 88/2013/DSOZ]. Polish.

4. Kapłunowska J, Nowicki P. [Public relations as a tool for building the image of private health care facilities]. Nurs Public Health. 2011;1(1):47-55. Polish.

5. Public Opinion Research Center. [User reviews develops health care. The message of the study] [Internet]. Warszawa: The Center; 2010 [cited 2015 Jun 29]. Available from: http://www.cbos.pl/PL/publikacje/public_ opinion/2010/01_2010.pdf. Polish.

6. Opolski K, Dykowska G, Możdżonek M. [Quality management in health services]. Warszawa: CeDeWu; 2011. Polish.

7. Wrońska I, Piskorz K. [The impact of hospital accreditation on the quality of nursing care]. Public Health. 2004;4(114):545-8. Polish.

8. Aiken LH, Sermeus W, van den Heede K, Sloane DM, Busse R, McKee M, et al. Patient safety, satisfaction, and quality of hospital care: Cross sectional surveys of nurses and patients in 12 countries in Europe and the United States. BMJ. 2012;344:e1717, http://dx.doi.org/10.1136/ bmj.e1717.

9. Main Council of Nursing and Midwifery. [Preliminary assessment of nurse and midwife staff resources in Poland]. Warszawa: The Council; 2010. Polish.

10. Aiken LH, Patrician PA. Measuring organizational traits of hospitals: The revised nursing work index. Nurs Res. 2000;49(3):146-53, http://dx.doi.org/10.1097/00006199200005000-00006.

11. Corley KG, Cochran PL, Comstock TG. Image and the impact of public affairs management on internal stakeholders. J Public Aff. 2001;1:53-78, http://dx.doi. org/10.1002/pa.50.

12. Public Opinion Research Center. [Prestige of occupations]. Warszawa: The Center; 2013 [cited 2016 Jul 6]. Available from: http:// http://www.cbos.pl/SPISKOM. POL/2013/K_164_13.PDF. Polish. 
13. Sermeus W, Aiken LH, van den Heede K, Rafferty AM, Griffiths P, Moreno-Casbas MT, et al. Nurse forecasting in Europe (RN4CAST): Rationale, design and methodology. BMC Nurs. 2011;10:6, http://dx.doi.org/ 10.1186/1472-6955-10-6.

14. Lake ET. Development of the practice environment scale of the nursing work index. Res Nurs Health. 2002;25: 176-88, http://dx.doi.org/10.1002/nur.10032.

15. Maslach C, Jackson SE. The measurement of experienced burnout. J Organ Behav. 1981;2:99-113, http://dx.doi. org/10.1002/job.4030020205.

16. Zhan C, Kelley E, Yang HP, Keyes M, Battles J, Borotkanics RJ, et al. Assessing patient safety in the United States: Challenges and opportunities. Med Care. 2005;43 Suppl 3:142-7.

17. Hughes RG, Clancy CM. Nurses' role in patient safety. J Nurs Care Qual. 2009;24(1):1-4, http://dx.doi. org/10.1097/NCQ.0b013e31818f55c7.

18. Leiter MP, Spence Laschinger HK. Relationships of work and practice environment to professional burnout: Testing a causal model. Nurs Res. 2006;55(2):137-46, http://dx.doi.org/10.1097/00006199-200603000-00009.

19. Dudzik-Urbanek E, Kutaj-Wąsikowska H, Kutryba B, Piotrowski M, editors. [Hospital accreditation program. A set of standards]. Kraków: Centre for Monitoring Quality in Health Care; 2009. Polish.

20. Humpel N, Caputi P. Exploring the relationship between work stress, years of experience and emotional competency using a sample of Australian mental health nurses. J Psychiatr Ment Health Nurs. 2001;8(5):399-403, http:// dx.doi.org/10.1046/j.1365-2850.2001.00409.x.

21. Kosińska M, Pilarz Z. [Nurses' job satisfaction and some personal determinants]. Ann Univ Mariae CurieSklodowska [Med]. 2005;60(236 Suppl 16):46-53. Polish.
22. Demir A, Ulusoy M, Ulusoy MF. Investigation of factors influencing burnout levels in the professional and private lives of nurses. Int J Nurs Stud. 2003;40:807-27, http:// dx.doi.org/10.1016/S0020-7489(03)00077-4.

23. Patrick K, Lavery JF. Burnout in nursing. Aust J Adv Nurs. 2007;24(3):43-8.

24. Aiken LH, Clarke SP, Sloane DM, Sochalski J, Silber JH. Hospital nurse staffing and patient mortality, nurse burnout, and job dissatisfaction. JAMA. 2002;288(16): 1987-93, http://dx.doi.org/10.1001/jama.288.16.1987.

25. Piko BF. Burnout, role conflict, job satisfaction and psychosocial health among Hungarian health care staff: A questionnaire survey. Int J Nurs Stud. 2006;43(3): 311-8, http://dx.doi.org/10.1016/j.ijnurstu.2005.05.003.

26. Wu S, Zhu W, Wang Z, Wang M, Lan Y. Relationship between burnout and occupational stress among nurses in China. J Adv Nurs. 2007;59(3):233-9, http://dx.doi. org/10.1111/j.1365-2648.2007.04301.x.

27. Kwak C, Chung BY, Xu Y, Eun-Jung C. Relationship of job satisfaction with perceived organizational support and quality of care among South Korean nurses: A questionnaire survey. Int J Nurs Stud. 2010;47(10):1292-8, http://dx.doi.org/10.1016/j.ijnurstu.2010.02.014.

28. Radkiewicz P, Widerszal-Bazyl M, Pokorski J, Pokorska J, Ogińska H, Pietsch E. [Why do nurses prematurely leave their profession?]. Bezpiecz Pr Nauka Prakt. 2004;7-8:31-4. Polish.

29. Kunecka D, Kamińska M, Karakiewicz B. [Analysis of factors determining job satisfaction among nurses. Preliminary research]. Nurs Top. 2007;2-3(15):191-6. Polish.

30. Sand A. Nurses' personalities, nursing-related qualities and work satisfaction: A 10-year perspective]. J Clin Nurs. 2003;12(2):177-87, http://dx.doi.org/10.1046/j.13652702.2003.00729.x.

This work is available in Open Access model and licensed under a Creative Commons Attribution-NonCommercial 3.0 Poland License / Ten utwór jest dostępny w modelu open access na licencji Creative Commons Uznanie autorstwa - Użycie niekomercyjne 3.0 Polska - http://creativecommons.org/ licenses/by-nc/3.0/pl/deed.en. 